\title{
Biomedical Science Students' Intended Graduate Destinations
}

\author{
Christian Panaretos $^{\mathrm{a}}$, Kay Colthorpe ${ }^{\mathrm{a}}$, Judit Kibedi ${ }^{\mathrm{a}}$ and Louise Ainscough ${ }^{\mathrm{a}}$ \\ Corresponding author: Kay Colthorpe (k.colthorpe@uq.edu.au)

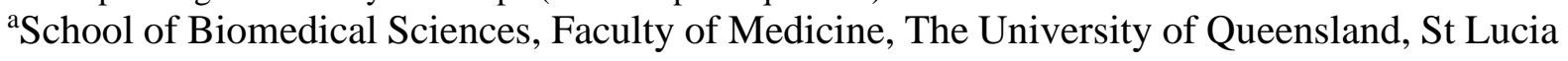 \\ Queensland 4072, Australia.
}

Keywords: biomedical science, graduate destinations, career pathways

\begin{abstract}
Undergraduate students enrolled in generalist degrees, such as biomedical science, have diverse potential graduate pathways that they may choose to pursue. The aims of this study were to evaluate the intended graduate destinations of students, the reasons they chose to study science and the perceived value of the skills they are acquiring for their intended profession. The participants were second year biomedical science students at the University of Queensland. Their responses to open-ended questions regarding their intentions, choices and perceptions were subjected to thematic analysis. Three-quarters of students mentioned one intended profession, with the remainder mentioning two or more. Overall, they identified 53 different intended graduate destinations in the fields of medicine $(69 \%)$, research $(34 \%)$, the science industry $(14 \%)$ and allied health $(8 \%)$. As reasons for studying science, students commonly reported their interest in science, the influence of role models and enjoyment or academic success in prior study. Many students, particularly those intent on pursuing medicine, said they planned to use science as a pathway to a postgraduate degree. Importantly, all students perceived that the skills they were acquiring in their degree were highly applicable to their future intended professions.
\end{abstract}

\section{Introduction}

\section{Overview}

For many university students, graduate pathways are defined by their choice of degree program, allowing them to develop specific knowledge and skills relevant to their intended graduate destination as they progress, and to assimilate the culture, values and norms of their intended professions (Boshuizen, Bromme, \& Gruber, 2006). However, for students in generalist programs, such as science, the diversity of potential careers available to them when they graduate means they may not know what their graduate destination will be. Students may undertake a science degree for varying reasons, perhaps through a desire to pursue a career in science, or as a pathway to another graduate program. Their satisfaction with the science curriculum may be influenced by the extent to which they perceive it prepares them for their desired future profession. For this reason, it is critical that science educators are cognisant of the diverse graduate intentions of science students, and create curricula that supports this diversity.

\section{Literature Review}

The ability of students to successfully acquire knowledge and skills allows them to prepare for future professional roles and make informed professional judgements (Kemmis, 2009). Existing literature assigns universities a salient role in the knowledge and skill acquisition of students (Cornelissen \& Van Wyk, 2007; Goldie, 2012). In a rapidly evolving society, the requirements of working professionals are changing, setting new demands on student education and training. Despite these changes, the expectation remains that universities produce graduates who exhibit a mastery of theoretical concepts, display competent application of these 
concepts in challenging workplace environments, and personify their professional role (Trede, Macklin, \& Bridges, 2012). For science academics and curriculum designers, this poses a challenge. Not only do they need to create a curriculum that provides students with strong foundations in disciplinary knowledge, but also with knowledge and skills which are broadly applicable. In addition, they must articulate the transferability and application of this knowledge and skills to their students' desired professions.

Graduates of a generalist degree such as biomedical science or science have a broad array of career options, including research and science professions, or they may use their degree as a pathway for further study in medicine or allied health. Although limited, existing data on graduate destinations suggests up to $15 \%$ of bioscience graduates pursue a career in research, $25 \%$ enter the science profession in other roles, $35 \%$ go on to further study (including medicine), while the remainder enter a diverse range of careers (Harris, 2012; "QILT Graduate Outcomes Survey," 2016; Sornapooman \& Fyfe, 2015). However, the desired destinations which students envisage whilst studying may not necessarily align with their ultimate graduate outcomes, and students may not even recognise the breadth of opportunities available to them (Choate, Green, Cran, Macaulay \& Etheve, 2016).

Potentially the use of practise-based pedagogies, such as the integration of authentic assessment tasks and opportunities for work-integrated learning, may address some of the challenges for both students and academics. These may allow students to become more aware of how their knowledge and skills are applicable to the workplace and aid development of professional identity (Hunter, Laursen, \& Seymour, 2007; Trede, 2012). But the broad array of career options available suggest that the opportunities provided must also be diverse. As such, academics need to be aware of the range of careers students aspire to. Currently there is a relative dearth of information identifying the career intentions of students undertaking generalist degrees, as well as how these intentions may change through their studies. Understanding students' desired destinations may facilitate more tailored curricular designs that develop their professional identity toward a specific career, or expose students to different career opportunities to bridge the mismatch between intended and final destinations.

Given the diverse destinations in generalist degrees such as biomedical science, it would be beneficial to understand how these students' graduate intentions develop both prior to and during their undergraduate degree. Therefore, the aims of this study were to (i) identify the intended graduate destinations of biomedical science students, (ii) evaluate the reasons they chose to study science and (iii) determine the extent to which they perceive the skills they were acquiring will be valuable for their future professions. To address these aims, this study was conducted using a mixed methods approach, utilising both qualitative and quantitative analyses.

\section{Methods}

\section{Course and participants}

The students in this study were undertaking the second year 'Integrative Cell and Tissue Biology' course in semester 1, 2018. This course has a cohort of 559 students, the majority of whom are enrolled in their second year of the Bachelor of Biomedical Science $(n=286)$, Bachelor of Science $(n=199)$ and Bachelor of Advanced Science $(n=40)$, with the course being core to the biomedical major of all three degrees. Among these students were 111 who had provisional entry into the Doctor of Medicine program at the University of Queensland. 
The remaining students were in the Bachelor of Biotechnology $(n=5)$, Engineering $(n=5)$ or various Science dual degrees.

The average cohort age was 20.3 years. Approximately $60 \%$ were female, and $13 \%$ were international students. Course assessment comprised two laboratory reports, two 'metalearning' tasks (Colthorpe, Sharifirad, Ainscough, Anderson, \& Zimbardi, 2018) in weeks 2 and 12 of semester, and an end-of-semester examination. Contact hours consisted of three, 1hour lectures per week, and five 3-hour practical classes spread across the 13 weeks of semester.

\section{Ethical considerations}

Approval was granted by the University of Queensland's Human Research Ethics Committee. Each student in the course received a participant information sheet and was invited to provide informed consent, with 483 (86\% of the cohort) doing so. An unpaired, two-tailed t-test was used to compare academic performance between consenting students (mean $65.7 \pm 0.7 \%$ SEM) and the entire cohort $(64.2 \pm 0.7 \%, \mathrm{p}=0.13)$. As no significant differences were found, participants were considered academically representative of the cohort. All data from consenting students was de-identified and assigned a unique code, so that demographic, qualitative and quantitative data for each student could be matched.

\section{Data collection and analysis}

To identify students' intended graduate destination(s) and reasons for choosing to study science, a meta-learning question in the first task asked students to describe "What are the most influential factors in your decision to study science? What job/profession do you hope it will ultimately lead you to?" In the second meta-learning task, students were asked "How applicable do you think the skills (such as communication, critical thinking, or quantitative skills) that you are learning in your science degree are to your future intended profession? Why?"

Qualitative responses to these meta-learning questions were subjected to inductive thematic analysis (Braun \& Clarke, 2006) using NVivo $11^{\mathrm{TM}}$ software (QSR International, MA, USA), which enabled categorisation of qualitative data and produced quantitative results through theme frequencies. Coding of individual responses often generated multiple themes, such as in these example student responses (italics) with their resultant themes (bold):

My decision to study science has been largely influenced by my curiosity and interest in understanding the natural world, [curiosity about the world] a passion which Ifeel has always been there, but which in part has probably been passed onto me by the passion of my own teachers [role models]....

I feel that the communication and critical thinking skills I have picked up from these practicals will be crucial in my future intended profession (being Medicine). Critical thinking is an imperative skill, as I feel I will be exposed to a vast number of new scenarios, in which I will have to effectively problem solve and come up with a solution [problem solving]. As well as this, communication will be vital to effectively get the point across to patients [patient treatment].

The intended graduate destinations of biomedical science students were inductively coded into categories which encompassed a variety of professional specialities and sub-specialities. This categorisation allowed the development of a 'profile' for each destination group which was 
used to elucidate commonalities and differences between groups, based on their response frequency, expressed as the percentage of students within the respective group.

Reliability of all coding was evaluated by inter-rater reliability scores. A second researcher coded $25 \%$ of the data, with an initial coding agreement of $82 \%-84 \%$. Discrepant responses were discussed until consensus was reached, and coding modified accordingly.

\section{Statistical analysis}

Academic performance of students in each intended graduate destination group was subjected to one-way analysis of variance (ANOVA) in Prism $^{\mathrm{TM}}$ (GraphPad, San Diego, CA, USA). The frequency of responses among groups regarding reasons for studying science and skill applicability were compared using Chi-square tests of independence in SPSS ${ }^{\mathrm{TM}}$ (IBM Statistics, NY, USA), as were the frequency of intended graduate destinations of students in each program. Results are expressed as mean and standard deviation, and significance determined at $\mathrm{p}<0.05$.

\section{Results}

\section{Biomedical science students' intended graduate destinations}

Most students (73\%) reported just one intended graduate destination, 21\% reported two, 3\% three, and one student mentioned having four intended destinations. There were a further 14 students who did not mention, or said they had not yet decided, on a graduate destination. Overall, responding students $(\mathrm{n}=483)$ identified 53 different intended graduate destinations (Figure 1). Although many identified a general professional field, saying for example, "medicine" or "research", others identified specific roles, such as "orthopaedic surgeon" or "neuroscientist". Grouped by field, destinations mentioned were in medicine (69\%), research (34\%), the science industry (14\%) and allied health (8\%). Of the 116 students who mentioned two or more destinations, 89 had destinations that spanned professional fields.

Within these professional fields, each comprised various disciplines or specialties. Of the students who intended to pursue medicine (n=332), 256 simply cited "medicine" as their intended profession. Surgery was the highest reported medical speciality $(n=33)$, spanning seven sub-specialities ranging from plastic surgery to neurosurgery. Ten students intended to become general practitioners, and a further 33 students mentioned 16 different medical specialities. Similarly, half the students who intended to pursue research $(n=161)$ simply stated "research" as their destination. Those who were more specific identified 17 research disciplines, with neuroscience $(n=18)$ and medical research $(n=17)$ being the most frequently mentioned.

Some students $(\mathrm{n}=54)$ cited intended graduate destinations beyond health and research but still within the science industry, including science teaching $(n=17)$, biomedical engineering $(n=8)$ and science communication $(\mathrm{n}=6)$. A further 14 science professions were each mentioned by 1-3 students, spanning from biotechnology to medical illustrator.

Of those who intended to pursue a career in allied health $(n=39), 12$ were aiming for physiotherapy and three for occupational therapy. The disciplines of audiology, dentistry, pharmacy and psychology were each reported by two students, whilst chiropractor, dietetics, nursing, nutrition, physician's assistant, radiography, sonography and speech pathology were each reported by one student. The remaining students $(n=8)$ simply said "allied health". 


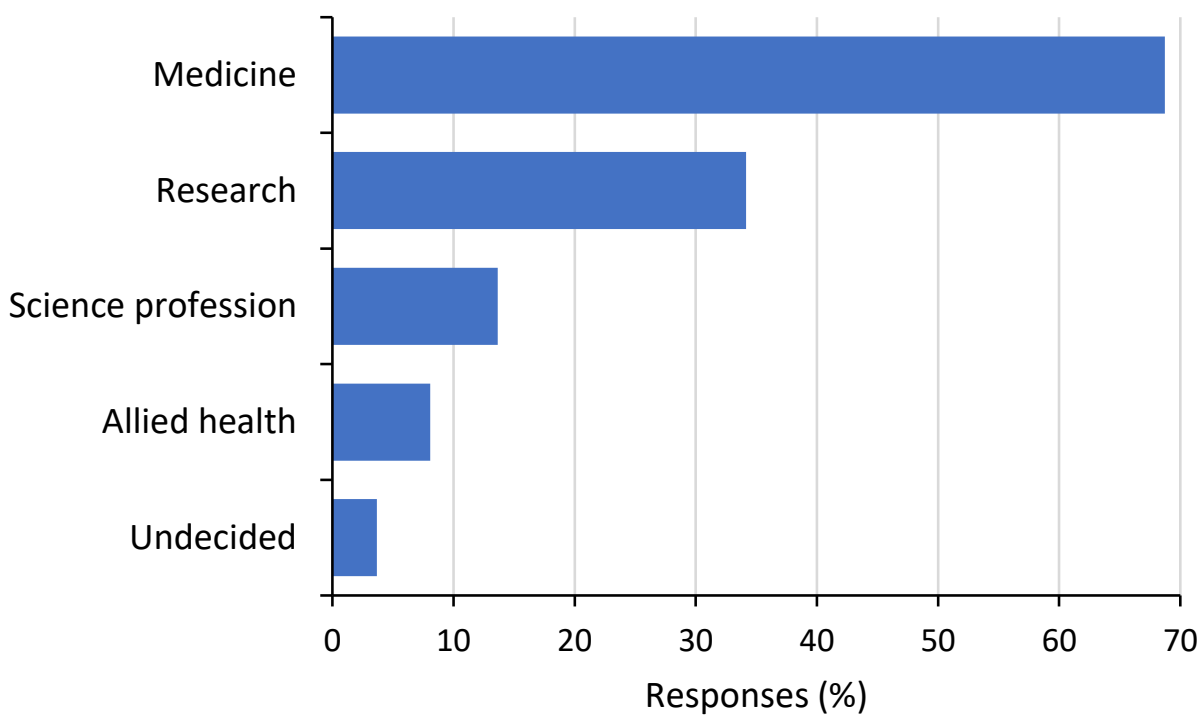

Figure 1: Frequency of intended graduate destinations of biomedical science students $(n=483)$, grouped by professional field. Students could provide more than one field in their response, with $18 \%$ doing so. A total of 53 different graduate destinations were mentioned.

\section{Destination profiling}

Based on students' primary intended graduate destination, students could be categorised into the professional fields of medicine, research, science profession or allied health. Most students were categorised in the medicine destination profile $(n=268)$, followed by research $(n=83)$, science profession $(n=32)$ and allied health $(n=16)$. Although 89 students reported intended destinations that spanned more than one professional field, most described one as the primary profession they were pursuing, with the other profession(s) offered as an alternative, these students were therefore categorised based on their primary intended destination. However, among these were 34 students who ranked professions from two different professional fields equally, saying they intended to pursue both with equal desire. To account for these students, a 'dual' destination profile was created. Of these students, the majority $(n=24)$ intended to pursue medicine and research, seven said they were equally committed to medicine and allied health, with the remainder pursuing allied health and research. Students who either did not indicate a graduate destination $(n=14)$ or had incomplete datasets $(n=36)$ were excluded from the profile groups. Consenting students among the cohort who had provisional entry into the graduate medical program appeared among either the medicine group $(n=86)$ or in the dual destination group ( $n=9)$, representing $32 \%$ and $37 \%$ of each group respectively. Thus, the total number of students who intended to pursue medicine either solely or as a dual destination $(n=299)$ far exceeded the number who had provisional entry into medicine $(n=95)$.

To evaluate if students in destination groups differed in academic performance, the course grades for students in each destination profile were compared by one-way ANOVA. No significant differences in grades were found between groups. A similar analysis was performed on examination marks for each group, but again no significant differences were seen between groups.

When considered based on the program in which they were enrolled, consenting students in the Bachelor of Science $(n=152)$ and Bachelor of Biomedical Science $(n=204)$ had a very 
similar spread of intended graduate destinations (Figure 2). Chi-square analysis showed no significant differences in graduate destinations between these two programs, despite there being slightly more students who had provisional entry into medicine in the Bachelor of Science $(n=54)$ than in the Bachelor of Biomedical Science $(n=38)$. The intended graduate destinations of students in the Bachelor of Advanced Science $(n=35)$ differed from the other programs, in that significantly more planned on pursuing research $(63 \%, \mathrm{p}<0.001$; Figure 2$)$. However, there were still nine students $(26 \%)$ in this program who intended to pursue medicine, with a further four intending to pursue both research and medicine equally, but none said they intended to pursue a career in allied health or the science professions.

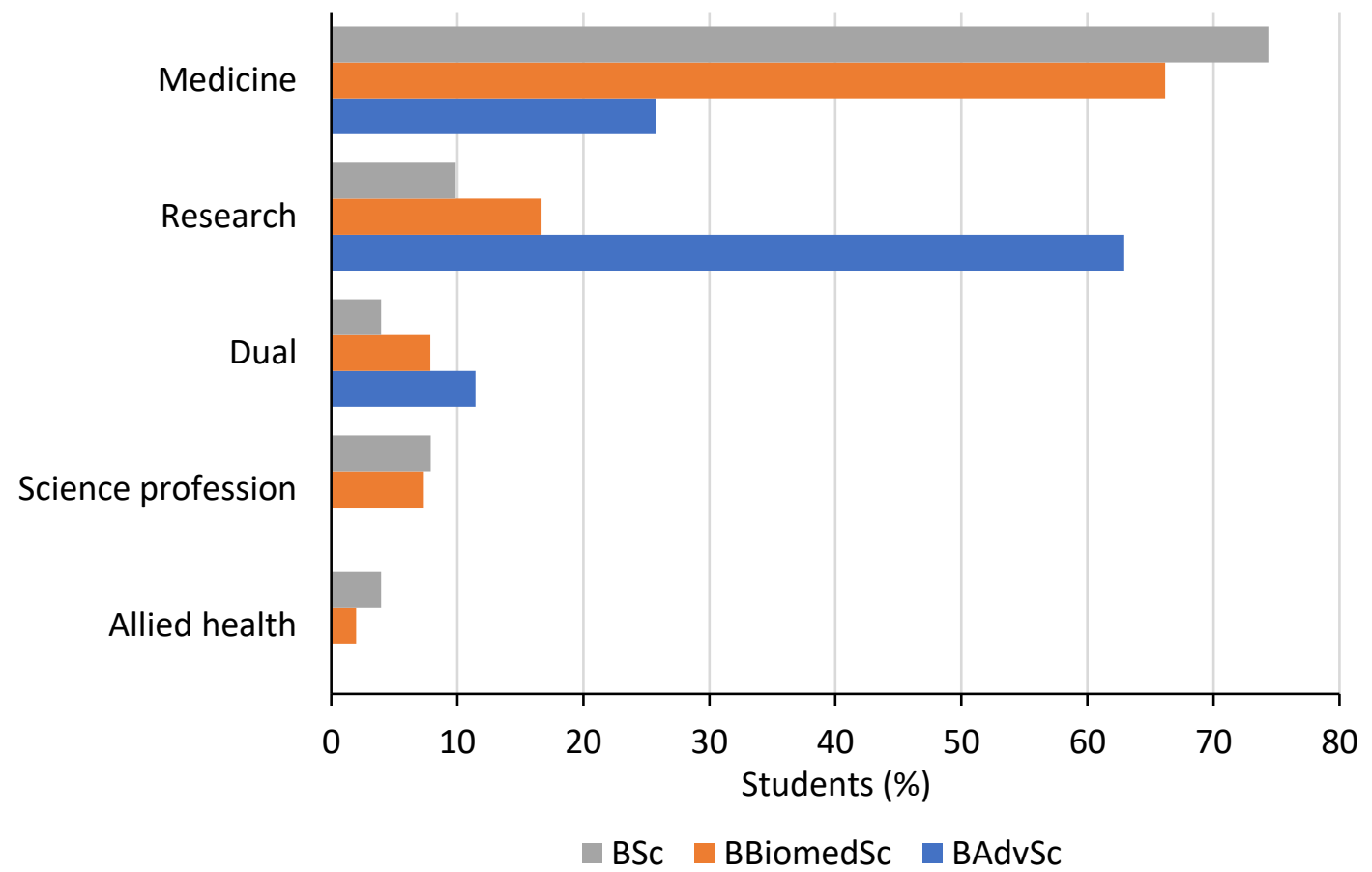

Figure 2: Intended graduate destinations of students enrolled in the Bachelor of Science (grey bars; $n=152$ ), Bachelor of Biomedical Science (orange bars; $n=204$ ) or Bachelor of Advanced Science (blue bars; $n=35$ ). Results are shown as a percentage of students in each program. Chi-square tests of independence showed students in the Bachelor of Advanced Science were significantly $(p<0.001)$ more likely than expected to report research as their intended graduate destination.

\section{Reasons students choose to study science}

Biomedical science students described reasons which influenced their decision to study science, with many reporting multiple reasons. A total of 231 reasons of 13 different types were identified across all respondents $(n=483)$. The most commonly reported reason was their interest in science (43\% of respondents), prior study they had completed (36\%), with students mentioning enjoyment, interest generated or academic success in prior study as motivations (Table 1). Many students (29\%) said they planned to use science as a pathway to a postgraduate degree, with $87 \%$ of these students intending to pursue medicine. Just over a quarter of students listed role models as an influential factor $(27 \%)$. Almost two-thirds of these role models were family members, with the remainder being non-familial, predominantly school teachers (Table 1). 
Students in different destination profiles varied in the reasons they provided for choosing to study science (Figure 3). Chi-square tests indicated that students intending to pursue medicine were significantly more likely to report that their postgraduate aspirations influenced their degree choice, with $40 \%$ doing so, but were significantly less likely to indicate a desire to create change or being influenced by role models. In contrast, students intending to pursue research were significantly more likely to mention a desire to create change $(34 \%)$, and less likely to mention postgraduate aspirations as contributing to their decision to study science. Dual destination respondents were significantly more likely to indicate they were influenced by role models, with $57 \%$ doing so. 
Table 1: Frequency ( $\%$ of respondents), descriptions and examples of reasons biomedical science students ( $\mathrm{n}=483$ ) chose to study science. Coding descriptions were formulated from an inductive analysis of student responses, students could mention more than one reason.

\begin{tabular}{|c|c|c|c|}
\hline Reason & $\%$ & Description & Example \\
\hline Interest in science & 43 & $\begin{array}{l}\text { Expressed an interest or passion for science } \\
\text { (including specific disciplines) }\end{array}$ & $\begin{array}{l}\text { As science is a great passion of mine, it made a great deal of sense to pursue a } \\
\text { science-related field of study }\end{array}$ \\
\hline Prior study & 36 & $\begin{array}{l}\text { Responses which highlight academic success, } \\
\text { enjoyment or interest generated during prior study }\end{array}$ & $\begin{array}{l}\text { A strong enjoyment of biology and chemistry in high school pushed me towards } \\
\text { science at university }\end{array}$ \\
\hline $\begin{array}{l}\text { Postgraduate } \\
\text { aspirations }\end{array}$ & 29 & $\begin{array}{l}\text { Chose to study science as a "bridge" or "stepping- } \\
\text { stone" towards further study }\end{array}$ & $\begin{array}{l}\text { The most influential factor of why I am studying science is to provide a solid } \\
\text { foundation for future studies in medicine... }\end{array}$ \\
\hline Role models & 27 & $\begin{array}{l}\text { Responses mention a familial or non-familial role } \\
\text { model }\end{array}$ & $\begin{array}{l}\text {...most likely my family and my high school teachers. Both encouraged me to } \\
\text { pursue a career in science from a relatively young age }\end{array}$ \\
\hline $\begin{array}{l}\text { Curiosity about } \\
\text { the world }\end{array}$ & 23 & $\begin{array}{l}\text { Students who were inquisitive or curious about } \\
\text { phenomena within the natural world }\end{array}$ & $\begin{array}{l}\text {...my innate inquisitive nature and compulsion to find solutions, which I find is } \\
\text { best satisfied through the scientific discipline }\end{array}$ \\
\hline Create change & 19 & $\begin{array}{l}\text { To create change generally, make new discoveries, } \\
\text { societal or technological advancements }\end{array}$ & $\begin{array}{l}\text { I have always really wanted to pursue a career that will have a positive impact } \\
\text { in the lives of others and ultimately make some difference in the world }\end{array}$ \\
\hline Help people & 14 & Expressed a desire or goal to assist others & $\begin{array}{l}\text { I really wanted to make a difference and help people, maybe develop a vaccine } \\
\text { or contribute to the cure of a disease. }\end{array}$ \\
\hline Learn new things & 13 & $\begin{array}{l}\text { Desire to acquire new information to better } \\
\text { understand phenomena }\end{array}$ & $\begin{array}{l}\text { One of the most influential factors that pushes me to study science is the idea of } \\
\text { constantly learning new and exciting things }\end{array}$ \\
\hline $\begin{array}{l}\text { Diversity of } \\
\text { content or career }\end{array}$ & 9 & $\begin{array}{l}\text { Value of diversity either within degree or future } \\
\text { career }\end{array}$ & $\begin{array}{l}\text { The most influential factors for me in deciding to study science is that it covers } \\
\text { such a diverse range of topics and areas of study }\end{array}$ \\
\hline $\begin{array}{l}\text { Importance of } \\
\text { science }\end{array}$ & 8 & $\begin{array}{l}\text { Recognise importance and relevance of science to } \\
\text { the world }\end{array}$ & $\begin{array}{l}\text { Science is important to humanity. Its very advanced, innovative and } \\
\text { interesting. Its worth to spend a life for }\end{array}$ \\
\hline $\begin{array}{l}\text { Work or } \\
\text { extracurricular } \\
\text { experience }\end{array}$ & 4 & $\begin{array}{l}\text { Interest generated through exposure to science in } \\
\text { voluntary/paid work or extracurricular activities }\end{array}$ & $\begin{array}{l}\text { My passion for the science field flourished when I started working as a dental } \\
\text { assistant and receptionist for a dental surgery }\end{array}$ \\
\hline $\begin{array}{l}\text { Preferable to } \\
\text { former profession }\end{array}$ & 4 & $\begin{array}{l}\text { Had previously studied or worked in another, less } \\
\text { desirable profession }\end{array}$ & $\begin{array}{l}\text { I am an ex-chartered accountant with four years of experience in public tax } \\
\text { consulting. After traveling down this career path I found myself bored, } \\
\text { demotivated, and desiring a more meaningful purpose }\end{array}$ \\
\hline $\begin{array}{l}\text { Exposure to } \\
\text { illness or death }\end{array}$ & 3 & $\begin{array}{l}\text { Personal experience of illness or death led to a } \\
\text { desire to contribute to improvement }\end{array}$ & $\begin{array}{l}\text {...my exposure to diabetes with a grandparent who was managing the disease } \\
\text { sparked my first interest in biology and physiology }\end{array}$ \\
\hline
\end{tabular}




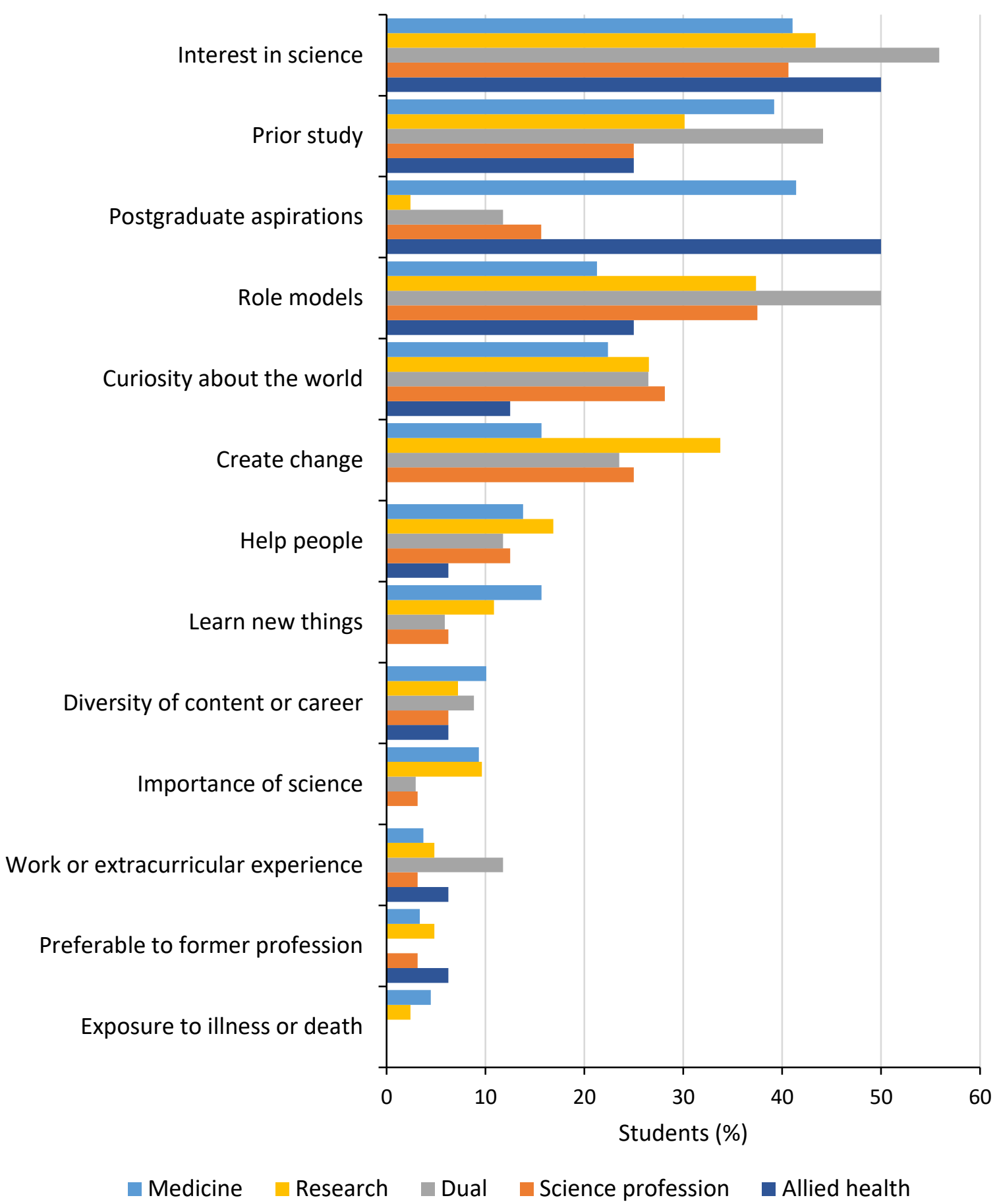

Figure 3: Biomedical science students $(n=433)$ provided a total of 231 reasons for their decision to study science. Student responses are grouped by their destination profile, with allied health (dark blue bars; $n=16$ ), science profession (orange bars; $n=32$ ), dual (grey bars; $n=34$ ), research (yellow bars; $n=83$ ) or medicine (light blue bars; $n=268$ ).

\section{Biomedical science students' skill applicability}

Students were asked to identify which skills they were learning (such as communication, critical thinking, or quantitative skills) they believed would be applicable to their intended professions. Those who responded $(n=352)$ identified eight different skills, with three of these being forms of communication. Students specified skills either individually or in combination, 
or referred to "all the skills" generally. Students most commonly identified writing skills (30\% of respondents), followed by communication (17\%), problem solving (14\%), critical thinking $(14 \%)$, verbal (5\%), technological (5\%) and time management (1\%) skills as being applicable (Figure 4). However, most (81\%) simply referred to "skills" in general as applicable (Figure 4). When considered by intended destination groups, students in each group expressed that the various skills were applicable to their intended profession at similar levels. The one exception was technological proficiency. While infrequently mentioned overall, it was more likely to be mentioned by students in the science profession group (16\% of group), than students in other groups.

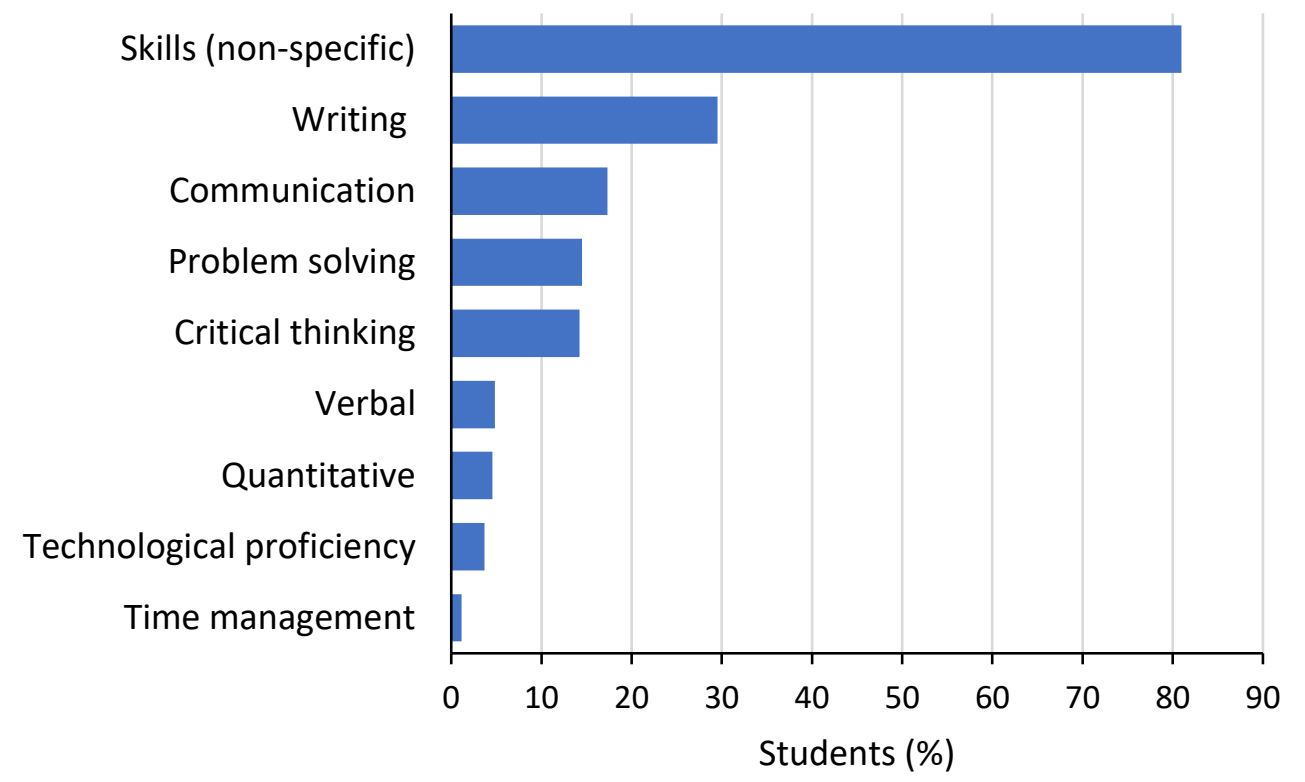

Figure 4: Skills that biomedical science students $(n=352)$ perceive to be applicable to their intended graduate destinations. Students could mention more than one skill in their response, with $54 \%$ doing so. A total of eight different skills were mentioned. 'Skills (nonspecific)' refers to students who cited skills generally but did not specify a type.

Students could also provide reasons why the skills they reported were applicable to their intended future profession, with 318 students citing 15 different reasons (Table 2). The most frequent, cited by $42 \%$ of students, was that as future professionals they would need to translate science to people of different demographics. Patient treatment $(28 \%)$, understanding literature (27\%), teamwork (25\%) and the broad applicability of science-based skills to a variety of professional roles $(25 \%)$ were also common reasons students gave for skill applicability (Table 2).

Chi-square tests showed that students from different destination groups gave significantly different reasons for skills being applicable to their future professions (Figure 5). Those in the medicine group were significantly more likely to cite patient treatment (mentioned by $39 \%$ of group) and understanding literature (30\%). Students in the dual profession group were more likely to mention career success, with $44 \%$ doing so, whereas those in the medicine group were less likely to (17\%). Surprisingly, students pursuing research were less likely than expected to mention understanding literature, with only $14 \%$ doing so. Finally, there were no students in the science profession group who mentioned patient treatment. 
Table 2: Frequency (\% of respondents), descriptions and examples of reasons biomedical science students ( $\mathrm{n}=318)$ consider the skills taught in their degree are applicable to their intended profession. Students could mention more than one reason.

\begin{tabular}{|c|c|c|c|}
\hline Reason & $\%$ & Description & Example \\
\hline $\begin{array}{l}\text { Translating } \\
\text { science }\end{array}$ & 42 & $\begin{array}{l}\text { Highlight translating science to people with } \\
\text { varying levels of scientific knowledge }\end{array}$ & $\begin{array}{l}\text { I need to communicate effectively to give accurate information succinctly to } \\
\text { enable people to understand what I'm researching }\end{array}$ \\
\hline Patient treatment & 28 & $\begin{array}{l}\text { Respondent aligns their acquired skill(s) with } \\
\text { critical aspects of patient treatment }\end{array}$ & $\begin{array}{l}\text { Communicative and critical thinking skills would also be highly important when } \\
\text { treating patients to build rapport and diagnose }\end{array}$ \\
\hline $\begin{array}{l}\text { Understand } \\
\text { literature }\end{array}$ & 27 & $\begin{array}{l}\text { Use skill(s) to understand scientific literature in } \\
\text { the future }\end{array}$ & $\begin{array}{l}\text { The ability to read and understand literature ... ensures I am practicing at the } \\
\text { highest standard and maintain a professional approach to all future endeavours }\end{array}$ \\
\hline Broad application & 25 & $\begin{array}{l}\text { Identification of the skill(s) as relevant to a } \\
\text { variety of professions or disciplines }\end{array}$ & $\begin{array}{l}\text { All the skills I am being taught in my science degree are relevant in any future } \\
\text { profession }\end{array}$ \\
\hline Teamwork & 25 & $\begin{array}{l}\text { Need skill(s), for collaboration within the } \\
\text { workplace }\end{array}$ & $\begin{array}{l}\text { Communication is key for working in a team, liaising with employers / supervisors } \\
\text { and networking with colleagues }\end{array}$ \\
\hline Career success & 23 & $\begin{array}{l}\text { Belief that skill(s) developed throughout degree } \\
\text { are key to occupational success }\end{array}$ & $\begin{array}{l}\text { Critical thinking is vital in being able to diagnose and/or complete your own } \\
\text { research and therefore be successful in your chosen field of work }\end{array}$ \\
\hline Aid data analysis & 22 & $\begin{array}{l}\text { Recognition of skill(s) as important in } \\
\text { effectively performing data } \\
\text { analysis/interpretation }\end{array}$ & $\begin{array}{l}\text { I will need quantitative skills to both be able to statistically evaluate data myself } \\
\text { and interpret statistical findings to inform my decisions as a practitioner. }\end{array}$ \\
\hline $\begin{array}{l}\text { Experimental } \\
\text { design }\end{array}$ & 14 & $\begin{array}{l}\text { Future experimental development and design } \\
\text { will be facilitated by their skill(s) }\end{array}$ & $\begin{array}{l}\text { I need to be able to perform quantitative analysis and understand what this } \\
\text { actually means, and also how to design a study with controls }\end{array}$ \\
\hline $\begin{array}{l}\text { Integrate } \\
\text { information }\end{array}$ & 14 & Integrate information from a variety of sources & $\begin{array}{l}\text {... required to integrate all the available information from a patient's symptoms } \\
\text { and results from diagnostic tests... to come up with an appropriate diagnosis }\end{array}$ \\
\hline $\begin{array}{l}\text { Foundation } \\
\text { knowledge }\end{array}$ & 14 & The skill(s) form a base for professional career & $\begin{array}{l}\text { These are all vital skills for creating a solid foundation for an extended profession } \\
\text { in science... }\end{array}$ \\
\hline Advance the field & 11 & $\begin{array}{l}\text { Express a desire to advance knowledge within } \\
\text { professional field }\end{array}$ & $\begin{array}{l}\text { In medicine, these skills are definitely required for research into new fields of } \\
\text { medicinal and pharmaceutical treatments }\end{array}$ \\
\hline $\begin{array}{l}\text { Aid decision } \\
\text { making }\end{array}$ & 10 & $\begin{array}{l}\text { Skills contribute to ability to make correct } \\
\text { decisions in professional setting }\end{array}$ & $\begin{array}{l}\text { Moreover, the critical thinking I am developing with all the courses I am taking } \\
\text { will help to make decisions when I become a professional }\end{array}$ \\
\hline $\begin{array}{l}\text { Avoid bad } \\
\text { practise }\end{array}$ & 6 & $\begin{array}{l}\text { Allow recognition of inappropriate or incorrect } \\
\text { behaviours/techniques/treatments }\end{array}$ & $\begin{array}{l}\text { Critical thinking and quantitative skills are applicable as realising that diagnostic } \\
\text { errors occur and identifying them is exceptionally important }\end{array}$ \\
\hline $\begin{array}{l}\text { Work under } \\
\text { pressure }\end{array}$ & 5 & $\begin{array}{l}\text { Give confidence to make rapid, appropriate } \\
\text { decisions }\end{array}$ & $\begin{array}{l}\text {... allow me to help patients in emergency situations, and make decisions on the } \\
\text { spot based on my knowledge and acquired skills }\end{array}$ \\
\hline $\begin{array}{l}\text { Novel treatments } \\
\text { or discoveries }\end{array}$ & 4 & $\begin{array}{l}\text { Allow recognition/critique of current knowledge } \\
\text { to aid development of new ideas }\end{array}$ & $\begin{array}{l}\text { Critical thinking is ... necessary to critique a method or idea and analyse it in } \\
\text { order to come up with new ideas or ways of going about a study }\end{array}$ \\
\hline
\end{tabular}




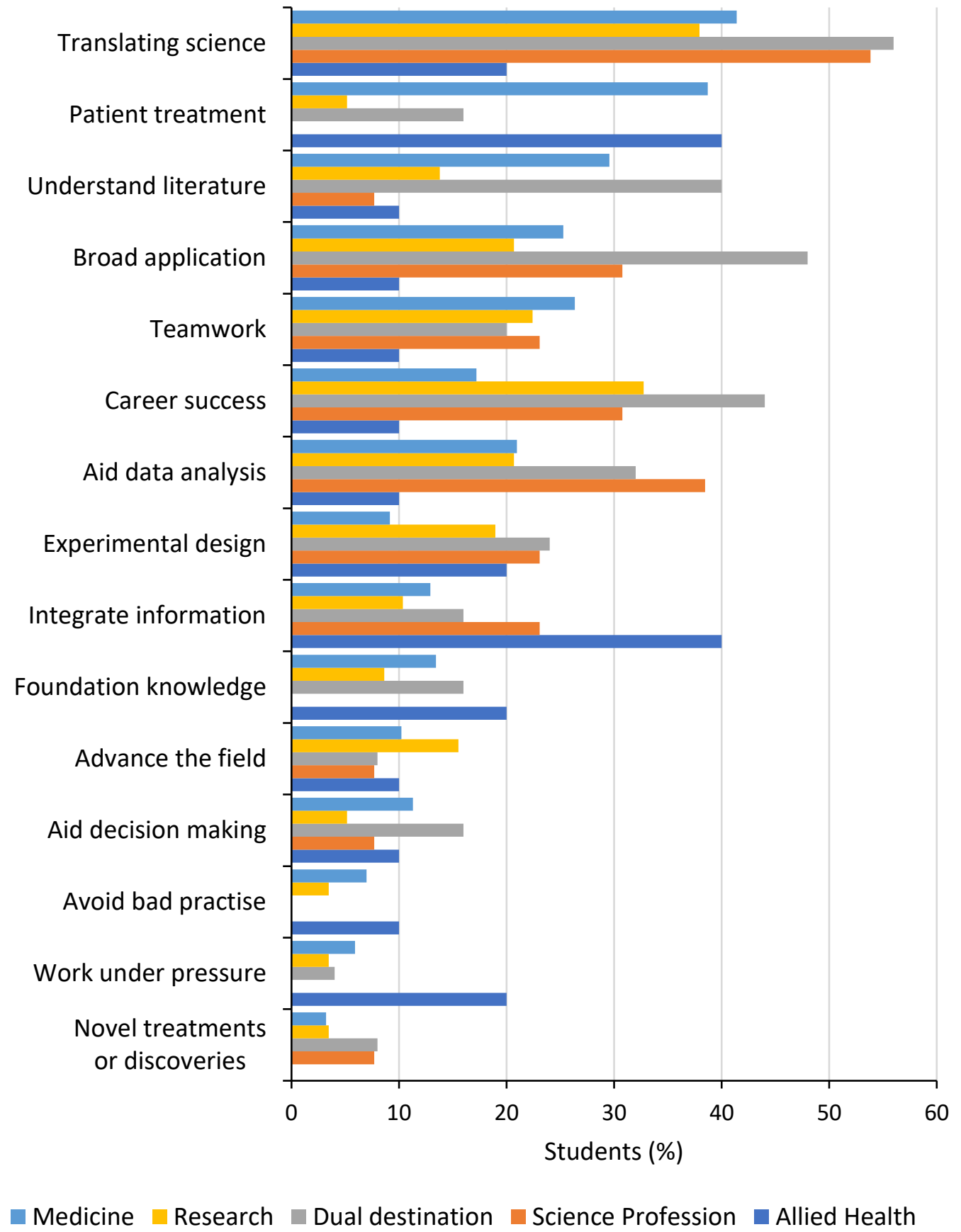

Figure 5: Reasons biomedical science students gave for applicability of skills to their future intended profession. Students are grouped by intended profession of allied health (dark blue bars; $n=10$ ), science profession (orange bars; $n=13$ ), dual (grey bars; $n=25$ ), research (yellow bars; $n=58$ ) or medicine (light blue bars; $n=186$ ), with results expressed as percent of students within each group. Students could provide more than one reason in their response.

\section{Discussion}

The aims of this study were to evaluate the intended graduate destinations of biomedical science students and to elucidate their reasons for studying science. Utilising open-ended 
questions allowed students to identify a broad range of intended graduate destinations, with students' responses showing that many have very specific destinations in mind. The initial meta-learning question prompted students to identify their career intentions, providing valuable information about the variety and multiplicity of students' intentions and allowing the creation of 'destination profiles'. In addition, we elicited students' perceptions of the value of their degree in providing skills that would be applicable to their future professions.

Students identified a total of 53 different desirable professions, with a quarter considering more than one future profession. Not unexpectedly, over two-thirds of these biomedical science students intend to pursue medicine following the completion of their degree, but this was well beyond the number who already had provisional entry into medicine. A third of students aspired to careers in scientific research, with some intending to pursue both professions. There are also a number of students who desire a career in allied health or in the science industry in some other way. Surprisingly, the intended graduate destinations of students studying in the Bachelor of Biomedical Science and Bachelor of Science programs did not differ. This may reflect the similarity between the biomedical science degree and major at the University of Queensland, as students are able to easily switch between these programs, and frequently do so. However, the graduate intentions of the small number of students in the Bachelor of Advanced Science did differ from those in other programs, in that they were much more likely to be pursuing research as a graduate destination. This is not unexpected given the strong research focus of this program.

These results contrast with existing graduate destination data for science or bioscience graduates (Harris, 2012; "QILT Graduate Outcomes Survey," 2016), but may reflect that students' career intentions, rather than employment outcomes, were analysed in this study. It should also be noted that the open-ended questions allowed students to provide multiple intended graduate destinations in their responses, so the cumulative percentage exceeds $100 \%$. This also meant that there were no limitations or confinements as to the responses, nor were students forced to rank one profession over another, where they may have seen both as equally desirable.

While the high desirability of a career in medicine was not surprising, given these students are studying biomedical science, both the number and specificity of graduate destinations mentioned by students was remarkable. In addition, while a quarter of these second year students mentioned two or more alternate professions, there were very few students who were completely undecided, with no professional destination already in mind. Many students also said they were extremely determined to follow their desired path, often already targeting a single profession. Despite this, some acknowledged that their professional intentions were evolving as they were exposed to more opportunities. For example, reflecting on their experiences over the semester, one student said:

\section{... I'm more exposed to alternate career paths that I could do if I got my PhD and did something other than medicine ... there was a moment this year that I was like, okay, what if I didn't do medicine and I actually become, I don't know, work for the university doing research.}

It is known that a student's professional identity is dynamic, developing as they progress through their study and transition into the workplace (Ibarra, 1999). So, while these findings provide a snapshot of students' professional intentions, they are likely to evolve as these students progress toward graduation and beyond. 
The primary intended destinations reported by students were used to create the destination groups of 'medicine', 'research, 'dual', 'science profession' and 'allied health'. This allowed profiling of the students in each group, in terms of their reasons for choosing to study science and their perceptions of the value of their degree. Rather surprisingly, the course grades and examination results of students in different destination groups did not differ significantly. It could reasonably be expected that students in the medicine and dual destination groups would have higher grades, given that these groups had a higher representation of students with provisional entry into the graduate medical program, and who therefore have high university entrance scores and ongoing performance requirements. Given the limited places available in medical programs in Australian universities, and the competitive nature of provisional and postgraduate acceptance, this finding suggests there are more similarly performing students who wish to pursue medicine than there are places. In addition, it is unlikely that students' desired destination choices are dictated solely by their academic achievement.

Students enter a science degree for many reasons, most often due to their interest in science, which may be generated through school or other study (Wang, 2013). Students often expressed a love of science, fascination with understanding how things work, and a curiosity about the world. Students also often expressed a desire to create change, particularly those intent on research. More pragmatically, students may see science as a pathway to their graduate destination, particularly those intending to continue study in medicine. Many students mentioned being influenced by role models. Individuals can employ role models in differing ways, drawing on their role models' favourable or unfavourable traits and behaviours completely or selectively (Gibson, 2003, 2004; Shapiro, Haseltine, \& Rowe, 1978). It has been shown that individuals in the early stages of their career draw positive inferences from role models that are personally close to them (Gibson, 2003). Given these students are in their second year of study, and therefore at a very early stage of progression toward their desired profession, it would be expected that they draw inferences from their closest role models. This was reflected by students' frequent reports of their family members and school teachers as positive role models.

A science degree is a generalist program. This means not only that graduates have multiple possible destinations, but that the knowledge and skills gained within the program should have broad applicability to an array of professions. However, science curricula are often perceived as being focused on disciplinary-specific content delivery and aimed primarily at the acquisition of skills applicable to scientific research (Neumann, 2001). Practise-based pedagogies, such as authentic assessment and work-integrated learning, can facilitate students' transition into their intended professions by developing their capability to use theory in a workplace setting (Higgs, McAllister, \& Whiteford, 2009; Hunter, Laursen, \& Seymour, 2007; Reid, Dahlgren, Petocz, \& Dahlgren, 2011; Trede, 2012; Wilson, Cowin, Johnson, \& Young, 2013). However, the implementation of such opportunities in science programs to date has been limited, and those that exist are often based in scientific research (Zimbardi \& Myatt, 2014). It is therefore heartening that in this study most students, regardless of their intended graduate destination, perceived that the skills they were acquiring in their science degree were highly applicable to their future professions, even though their reasons for believing so differed. This suggests that these students perceive their science degree to be a valuable step in the pathway to their intended graduate destination.

While the findings of this study provide valuable insights into the intentions of biomedical science students, they are subject to limitations, particularly due to the self-reported nature of 
the data obtained. While students provide rich and detailed responses to the meta-learning questions, not all provide objective information on the strength of their intentions or beliefs. Further, asking students to identify an intended graduate destination may have prompted undecided students to offer a destination that they may not have previously considered, giving the impression that the majority have actively considered their intentions. Finally, while these findings represent a snapshot of second year students studying biomedical science at the University of Queensland, they may not be representative of biomedical science students at other institutions or at all year levels. Indeed, it could be reasonably expected that students' intentions change as they approach graduation.

\section{Conclusion}

Whilst there is great benefit in the generalisability of the biomedical science degree, especially in terms of the diversity of professions it allows students to aspire to, some specialisation based on desired graduate destinations may favour the acquisition of specific professional skills. In addition, contact with staff who have experience in those professions may aid enculturation, allowing students to assimilate their culture, values and norms. This idea, and the findings of this study, were the basis of the development of profession 'streams' in the recently redesigned biomedical science capstone course at the University of Queensland. Students were able to select one of three possible streams; clinical, research or science-industry, and activities and assessment were contextualised for each stream. This allowed students to develop skills specific to those professions and importantly, access to teaching staff drawn from those professions, allowing them to meet and be mentored by individuals from their intended graduate destinations. This model could potentially be applied to other science programs and at earlier stages of study. Whilst inquiry-based laboratory classes provide students with research-focused opportunities, students intent on allied health or medicine may benefit professionally and academically from clinically relevant curricula and experiences. Student responses in this study also suggest an awareness about the link between medicine and research (see example response in Table 2). Integrating research and clinical curricular experiences and a broader exposure to experts in both areas could provide relevant role models for the diversity of students in these generalist degrees. Finally, offering students a choice of professionally relevant learning activities may increase their interest and engagement, as they may more clearly see the links between such activities and their graduate intentions.

\section{References}

Boshuizen, H. P., Bromme, R., \& Gruber, H. (2006). Professional learning: Gaps and transitions on the way from novice to expert (Vol. 2): Springer Science \& Business Media.

Braun, V., \& Clarke, V. (2006). Using thematic analysis in psychology. Qualitative Research in Psychology, 3(2), 77-101.

Choate, J., Green, J., Cran, S., Macaulay, J. \& Etheve, M. (2016). Using a professional development program to enhance undergraduate career development and employability. International Journal of Innovation in Science and Mathematics Education, 24(3), 49-70.

Colthorpe, K., Sharifirad, T., Ainscough, L., Anderson, S. T., \& Zimbardi, K. (2018). Prompting undergraduate students' metacognition of learning: implementing 'meta-learning' assessment tasks in the biomedical sciences. Assessment \& Evaluation in Higher Education, 43(2), 272-285.

Cornelissen, J., \& Van Wyk, A. (2007). Professional socialisation: An influence on professional development and role definition. South African Journal of Higher Education, 21(7), 826-841.

Gibson, D. E. (2003). Developing the professional self-concept: Role model construals in early, middle, and late career stages. Organization science, 14(5), 591-610.

Gibson, D. E. (2004). Role models in career development: New directions for theory and research. Journal of Vocational Behavior, 65(1), 134-156.

Goldie, J. (2012). The formation of professional identity in medical students: considerations for educators. Medical Teacher, 34(9), e641-e648. 
Harris, K. L. (2012). A background in science: What science means for Australian society. Australian Council of Deans of Science. Centre for the Study of Higher Education, University of Melbourne, Melbourne, Australia.

Higgs, J., McAllister, L., \& Whiteford, G. (2009). The practice and praxis of professional decision making. In B. Green (Ed.), Understanding and researching professional practice (7th ed., pp. 101-120). Rotterdam, The Netherlands: Sense Publishers.

Hunter, A. B., Laursen, S. L., \& Seymour, E. (2007). Becoming a scientist: The role of undergraduate research in students' cognitive, personal, and professional development. Science Education, 91(1), 36-74.

Ibarra, H. (1999). Provisional selves: Experimenting with image and identity in professional adaptation. Administrative Science Quarterly, 44(4), 764-791.

Kemmis, S. (2009). Understanding professional practice: A synoptic framework. In B. Green (Ed.), Understanding and researching professional practice (7th ed., pp. 19-38). Rotterdam, The Netherlands: Sense Publisher.

Neumann, R. (2001). Disciplinary differences and university teaching. Studies in Higher Education, 26(2), $135-$ 146.

QILT Graduate Outcomes Survey. (2016). Retrieved from https://www.qilt.edu.au/docs/default-source/gosreports/2016/gos-national-report.pdf?sfvrsn=423de23c_12

Reid, A., Dahlgren, M. A., Petocz, P., \& Dahlgren, L. O. (2011). Professional identity: how is professional identity developed? From Expert Student to Novice Professional (pp. 85-101). Dordrecht: Springer.

Shapiro, E. C., Haseltine, F. P., \& Rowe, M. P. (1978). Moving up: Role models, mentors, and the" patron system". Sloan Management Review (pre-1986), 19(3), 51.

Sornapooman, K., \& Fyfe, G. (2015). Exploring BSc Human Biology graduate outcomes and their perceptions of the course. Journal of Teaching and Learning for Graduate Employability, 6(1), 24-43.

Trede, F. (2012). Role of work-integrated learning in developing professionalism and professional identity. Asia-Pacific Journal of Cooperative Education, 13(3), 159-167.

Trede, F., Macklin, R., \& Bridges, D. (2012). Professional identity development: a review of the higher education literature. Studies in Higher Education, 37(3), 365-384.

Wang, X. (2013). Why students choose STEM majors: Motivation, high school learning, and postsecondary context of support. American Educational Research Journal, 50(5), 1081-1121.

Wilson, I., Cowin, L. S., Johnson, M., \& Young, H. (2013). Professional identity in medical students: pedagogical challenges to medical education. Teaching and Learning in Medicine, 25(4), 369-373.

Zimbardi, K., \& Myatt, P. (2014). Embedding undergraduate research experiences within the curriculum: a cross-disciplinary study of the key characteristics guiding implementation. Studies in Higher Education, 39(2), 233-250. doi:10.1080/03075079.2011.651448 